\title{
Amplification of Altered Self-reactive Cytolytic T Lymphocyte Responses by Cloned, Allospecific Human $T_{h}$ Cells
}

\author{
Steven M. Friedman, ${ }^{\star \star}$ Andrew Green, Carlo Russo, ${ }^{\ddagger}$ David N. Posnett, ${ }^{\star \star}$ Deirdre Diffley, and Mary K. Crow ${ }^{\star \star}$ \\ Departments of Medicine, ${ }^{*}$ The Hospital for Special Surgery, and the ${ }^{\ddagger}$ New York Hospital-Cornell University Medical College, \\ New York, New York 10021
}

\begin{abstract}
The effect of a cloned allospecific human $T_{h}$ cell, termed 86 , on the in vitro generation of altered self-reactive cytolytic $T$ lymphocytes (CTL) was investigated. Utilizing the induction of hapten altered self-reactive CTL as a model for virus or tumor-specific cell-mediated immunity, we determined that the presence of small numbers of clone 86 cells markedly amplified the generation of hapten altered self-reactive CTL. The killer cells induced belong to the $\mathrm{CD4}^{-}, \mathrm{CD8}^{+}$subset, are specific for the hapten-modified autologous stimulator cells present in culture, and are MHC class I restricted. The CTL induced under these culture conditions are readily expanded in the presence of IL-2 with maintenance of efficient and specific altered self-killing. Of interest, clone 86 cells preferentially enhance the growth of $\mathrm{CD8}^{+} \mathrm{T}$ cells and selectively amplify altered self-cytolysis but not NK cell activity. Although in vitro clone 86 cells mediate help for CTL generation via the production of lymphokines (IL-4 but little IL-2), one can envision immunotherapeutic strategies for human disease that involve the adoptive transfer of $T_{h}$ cells functionally analogous to clone 86.
\end{abstract}

\section{Introduction}

The development of effective, antigen specific, adoptive immunotherapy for tumors and intracellular infections represents a major objective of cellular immunology. In a number of experimental systems, considerable progress has been made toward achieving this goal. For example, virus or tumor antigen specific, murine cytolytic T lymphocytes (CTL), ${ }^{1}$ induced and/or expanded in vitro in the presence of antigen presenting cells and IL-2, have been shown to effectively augment cellmediated immunity upon in vivo transfer into virally infected or tumor-bearing syngeneic mice (1-4). In more recent studies by Cheever et al. (5), Friend virus leukemia specific CTL, grown in vitro in the presence of antigen presenting cells alone, were adoptively transferred and shown to both mediate

Address reprint requests to Dr. Friedman, The Hospital for Special Surgery, 535 East 70th Street, New York, NY 10021.

Received for publication 11 April 1988 and in revised form 6 June 1988

1. Abbreviations used in this paper: AFC, antibody-forming cells; CTL, cytolytic T lymphocytes; LAK, lymphokine-activated killer cells; NK, natural killer cells; $T_{h}, T$ helper cells; TNP, trinitrophenyl.

J. Clin. Invest.

(C) The American Society for Clinical Investigation, Inc.

0021-9738/88/11/1722/09 \$2.00

Volume 82, November 1988, $1.722-1730$ tumor-specific immunity and persist long term as functional memory $\mathrm{T}$ cells.

An alternative approach to adoptive immunotherapy involves the transfer of tumor antigen-specific helper $T\left(T_{h}\right)$ cells, which may mediate a tumoricidal delayed type hypersensitivity response directly, or augment a CTL response by the recipient animal's immune system. In some experimental models of tumor immunity, this approach has not only been successful, but considerably more effective than the transfer of tumor-specific CTL (6). While appealing, the direct application of this technique to human disease is complicated by the difficulty in generating $T_{h}$ cells specific for weak (i.e., tumor) antigens, the problems associated with MHC disparities between the $T_{h}$ cell donor and the tumor-bearing recipient, and the possibility of tumor antigen-specific suppressor $\mathrm{T}$ cells that can impede an effective immune response (7).

A potential strategy to circumvent these obstacles was suggested by our observation of functional heterogeneity among cloned human $T_{h}$ cell lines (8). We described two types of $\mathrm{CD}^{+}, \mathrm{CD}^{-}$allospecific $\mathrm{T}$ cell clones that mediate reciprocating helper functions: one preferentially triggers the differentiation of B cells into antibody forming cells (AFC), while the other selectively amplifies allospecific CTL responses. We postulated that these two functionally distinct $T_{h}$ subsets may differ with respect to the spectrum of lymphokines that they elaborate. More recently, evidence for a similar division of labor among $T_{h}$ cells has emerged in both the rat (9) and murine models (10).

The studies described in this report were designed to determine if cloned alloreactive human $T_{h}$ cells can be utilized to enhance CTL responses against more physiologically relevant targets, namely altered self cells. To this end, we have focused on the in vitro generation of human CTL that lyse hapten modified autologous lymphocytes. This model was chosen as the cellular interactions required for CTL generation (11) and effector cell specificity $(12,13)$ of hapten altered self-reactive CTL appear to be analogous to those for autologous tumor and virally infected cells (14-17). Our results demonstrate that selected allospecific $T_{h}$ cells can function to markedly amplify the in vitro generation of hapten-altered self-specific, $\mathrm{CD}^{-}$, $\mathrm{CD}^{+}$human CTL. These effector cells grow well in vitro and mediate extremely efficient cytolytic activity. While these allospecific $T_{h}$ cells function at least in part by the secretion of lymphokines, the capacity of $T_{h}$ cells to bind $(18,19)$ and present (19) antigen to the immune system suggests that these cells may permit a novel immunotherapeutic strategy for human diseases.

\section{Methods}

Isolation and fractionation of PBL. Fresh PBL were isolated from healthy volunteers by Ficoll-Hypaque centrifugation. T cells were iso- 
lated from non- $T$ cells by $E$ rosette formation with neuraminidasetreated sheep red blood cells and a second Ficoll-Hypaque centrifugation, as previously described (20). In some experiments, $T$ cell subsets were isolated by complement (c)-mediated lysis of the reciprocal subset according to a previously described protocol (11). Briefly, $10 \times 10^{6} \mathrm{~T}$ cells were resuspended in $1 \mathrm{~cm}^{3}$ of culture supernatant obtained from murine B cell hybridomas secreting antibody to the CD4 antigen, the CD8 antigen or, as a negative control, a monoclonal antibody that does not bind human $\mathrm{T}$ cells. After $30 \mathrm{~min}$ of incubation at room temperature, $1 \mathrm{~cm}^{3}$ of a 1:6 dilution of baby rabbit complement (c) was added and the cells incubated at $37^{\circ} \mathrm{C}$ in a shaking water bath for $1 \mathrm{~h}$. Cells were washed extensively before use as responder or effector $\mathrm{T}$ cells. The efficiency of c-mediated lysis was evaluated by determining the percentage of $\mathrm{CD}^{+}$and $\mathrm{CD}^{+}$cells in each treatment group by indirect immunofluorescent staining utilizing the flow cytometer.

Allospecific $T_{h}$ Clone 86 . Clone 86 is a DR 1 specific $\mathrm{T}_{\mathrm{h}}$ cell that has been described previously $(8,21)$. Briefly, clone 86 was derived from the limiting dilution culture of $T$ cells, obtained from a DR 2, 3 individual, which had been sensitized in vitro against $x$-irradiated stimulator cells obtained from a DR 1, 7-bearing donor. 86 cells have been expanded by repetitive stimulation with $\mathrm{DR} 1^{+} \mathrm{x}$-irradiated stimulator cells in the presence of $\mathrm{IL}-2$. Clone 86 cells are $\mathrm{CD}^{+}, \mathrm{CD}^{+}$, and $\mathrm{CD}^{-}$. In functional assays, 86 cells proliferate in response to $\mathrm{DR} 1^{+}$ stimulator cells. While 86 cells do not provide help for $\mathrm{DR} 1^{+} \mathrm{B}$ cell differentiation, the presence of 86 cells during in vitro sensitization markedly enhances the generation of allospecific CTL (8).

Hapten altered self-reactive CTL induction and effector assays. The in vitro generation and functional assay of hapten altered self-reactive human CTL have been described in detail $(20,22)$. Briefly, each sensitization culture consisted of 12-24 replicate microwells (Linbro MR-2; Flow Laboratories, Inc., Hamden, CT) containing $2 \times 10^{5}$ responder T cells and $1 \times 10^{5} \mathrm{E}$ rosette negative $\left(\mathrm{E}^{-}\right)$autologous stimulators in final medium. Final medium consisted of RPMI 1640 (Gibco Laboratories, Grand Island, NY) supplemented with $1 \%$ penicillin-streptomycin 200 $\mathrm{mM}$ l-glutamine, $2.5 \mathrm{mM}$ Hepes buffer, $0.05 \% \mathrm{Na} \mathrm{HCO}_{3}$ and $10 \% \mathrm{FCS}$ (all from Microbiological Associates, Bethesda, MD). Autologous stimulator cells were either unmodified or chemically derivitized with trinitrophenyl (TNP) or FITC as previously described $(20,22)$. Sensitization cultures were supplemented with final medium alone, clone $86 T_{h}$ cells, or clone $86 T_{h}$ culture supernatants, according to the experimental design. Unless otherwise stated, $1 \times 10^{4}$ clone 86 cells were added to each microwell at the initiation of cell culture. After $6 \mathrm{~d}$ of incubation at $37^{\circ} \mathrm{C}$ in a $5 \% \mathrm{CO}_{2}-95 \%$ air humid atmosphere, cultures were harvested. Viable cells were counted and assayed in triplicate at various effector to target ratios for cytotoxicity against ${ }^{51} \mathrm{Cr}$ labeled autologous target cells in a standard $4-\mathrm{h}{ }^{51} \mathrm{Cr}$ release assay (20). For clarity, results are presented as mean percent lysis. Standard error of all cytotoxic data points was $<4 \%$.

In some studies, CTL specificity was assessed by preincubating ${ }^{51} \mathrm{Cr}$-labeled target cells with a panel of monoclonal antibodies, including: W6/32, specific for a monomorphic determinant of class I HLA (23); CR11-351, specific for a polymorphic determinant of the HLA-A-2 antigen (24); GAPA-3 specific for a polymorphic determinant of the HLA-A-3 antigen; L243, specific for a monomorphic determinant of class II HLA; and NAMB-1 specific for B-2 microglobulin (24). GAPA-3 and L243 were purchased from American Type Culture Collection (Rockville, MD).

Preparation of clone $86 T_{h}$ cell culture supernatant. $1 \times 10^{6}$ clone 86 cells were cultured in $1 \mathrm{ml}$ of final medium with an equal number of $x$ irradiated $\mathrm{E}^{-}$stimulator cells obtained from $\mathrm{a} \mathrm{DR} 1^{+}$or a $\mathrm{DR} 1^{-}$allogeneic donor. In some studies, cultures were supplemented with $\sim 1$ $\mu \mathrm{g} / \mathrm{ml}$ of a monoclonal antibody, termed 19.1 , which was raised by Dr. Posnett and is specific for a private clonotypic determinant of the $\alpha-\beta$ chain $\mathrm{T}$ cell receptor expressed by clone 86 . After $36 \mathrm{~h}$ of incubation, cultures were centrifuged at $1,500 \mathrm{rpm}$ for $15 \mathrm{~min}$. Cell-free culture supernatants were isolated, passed through a $0.45 \mu \mathrm{m}$ filter (Millipore Corp., Bedford, MA) and stored frozen at $-70^{\circ} \mathrm{C}$ until used. To assay for help in the generation of altered self-reactive CTL, supernatants were added, at a final concentration of $30 \%, 24 \mathrm{~h}$ after the initiation of sensitization culture. Culture supernatants were assayed for IL-2 content by their capacity to support the proliferation of CTLL-2 cells (25). IL-4 was detected by the ability to induce BLAST-2 (CD-23) expression on resting tonsillar $B$ cells, a response that appears to be unique to IL-4 (26). In order to at least grossly quantitate the IL-2 and IL-4 content of culture supernatants, their biological activity was compared to a standard curve generated by known quantitities of recombinant (r)IL-4 (a generous gift from the DNAX Research Institute, Palo Alto, CA, prepared by Ms. Anita Van Kimmenade) and partially purified IL-2 (Electronucleonics, Inc., Silver Springs, MD).

\section{Results}

Allospecific $T_{h}$ cell-induced hapten altered self-reactive CTL. In previous studies, we observed that selected alloreactive human $T_{h}$ clones, including the DR 1 specific clone 86 , were potent amplifiers of allospecific CTL responses (8). In those experiments, coculture of 86 cells with autologous responder $T$ cells led to a vigorous CTL response directed against $\mathrm{MHC}$ determinants expressed on the $\mathrm{DR} 1^{+}$feeder cells used to propagate the 86 cell line. It should be emphasized that the $D R 1^{+}$ feeder cells were nonviable and, in the absence of viable 86 cells, no longer immunogenic. The CTL generated in these cultures were predominantly $\mathrm{CD}^{-}, \mathrm{CD}^{+}$and demonstrated specificity for MHC class I antigens expressed by the feeder cell (8).

In this report, we have studied the effects of cloned allospecific $T_{h}$ cells on the in vitro generation of human CTL which lyse hapten modified autologous lymphocytes as a model for tumor and viral immunity. To this end, clone 86 cells were added at the initiation of cultures containing responder $\mathrm{T}$ cells and either unmodified or TNP modified $\mathrm{x}$ irradiated autologous stimulator cells. To ensure antigen specific activation of the 86 cells, these studies were performed utilizing lymphocytes obtained from $D R 1^{+}$donors. The results of two representative experiments are presented in Fig. 1. As shown, cultures containing only responder $T$ cells and TNP modified autologous stimulators generate weak (Fig. $1 a$ ) or undetectable (Fig. 1 b) CTL responses against TNP modified autologous targets. The addition of clone 86 cells to responder $T$ cells and unmodified autologous stimulators does not induce CTL activity against TNP-modified target cells. In contrast, the combination of responder $\mathrm{T}$ cells, TNP modified autologous stimulators, and clone 86 cells results in a vigorous CTL response against the TNP-modified autologous target. As shown (Fig. 1 a) 86 cells markedly amplify an already existing CTL response, and (Fig. 1 b) can elicit a CTL response that is essentially undetectable in their absence. It should be noted that none of these effector cell populations lyse unmodified autologous target cells (data not shown).

Allospecific $T_{h}$ cell-induced altered self-reactive CTL are predominantly $C D 4^{-}, C D 8^{+}$. To characterize the altered selfreactive killer cells that are induced in this model, responder $T$ cells were sensitized against TNP modified autologous stimulators in the presence of clone 86 cells. After $6 \mathrm{~d}$, cultures were harvested and the recovered $T$ cells subjected to complementmediated lysis with anti-CD4, anti-CD8, or control antibody. The resulting populations were phenotyped with respect to $T$ cell subclass specific surface markers, to verify that the appropriate $T$ cell subset had been depleted, and assayed for cytolytic activity against unmodified and TNP-modified autologous targets. In agreement with our previous studies (8), TNP 


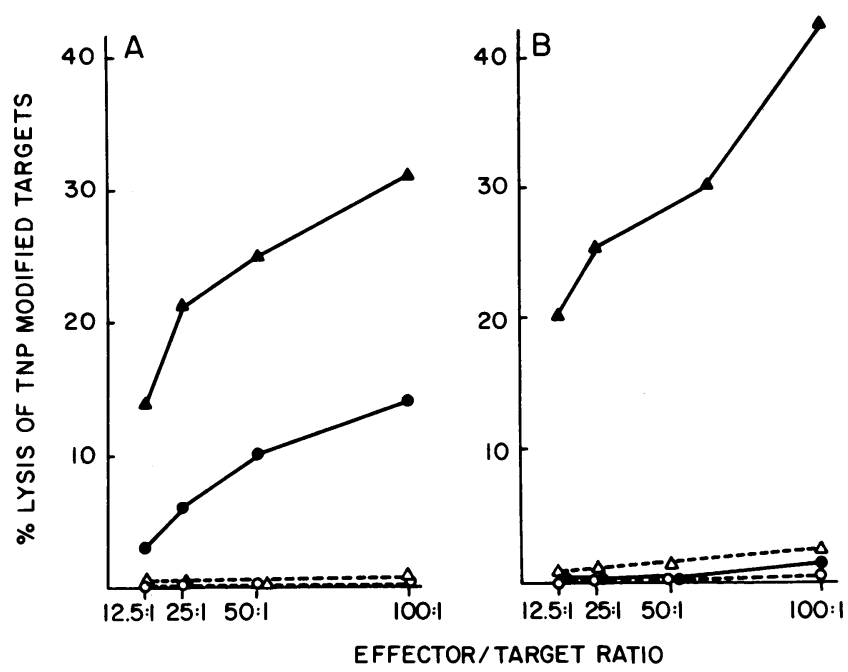

Figure 1. Allospecific $T_{h}$ clone 86 enhances altered self-cytolysis. Responder $\mathrm{T}$ cells were cocultured with $\mathrm{x}$-irradiated unmodified (open symbols, dotted lines) or TNP modified (closed symbols, solid lines) autologous $\mathrm{E}^{-}$stimulators. Cultures were supplemented with final medium $(0, \bullet)$ or clone 86 cells $(\Delta, \Delta)$. After $6 \mathrm{~d}$, cultures were assayed for cytotoxicity against unmodified and TNP modified autologous targets. As there was no significant lysis of unmodified targets, only cytolytic activity against the TNP modified target is shown.

altered self-reactive CTL generated in the presence of clone 86 cells are predominantly $\mathrm{CD}^{-}$and $\mathrm{CD}^{+}$(Fig. 2).

Allospecific $T_{h}$ cell-induced hapten altered self-reactive CTL demonstrate self preference. To determine if the TNP altered self-reactive CTLs induced in the presence of clone 86 $T_{h}$ cells are restricted by self MHC determinants, CTL populations were generated by coculture of responder T cells, TNPmodified autologous stimulator cells, and clone $86 T_{h}$ cells.
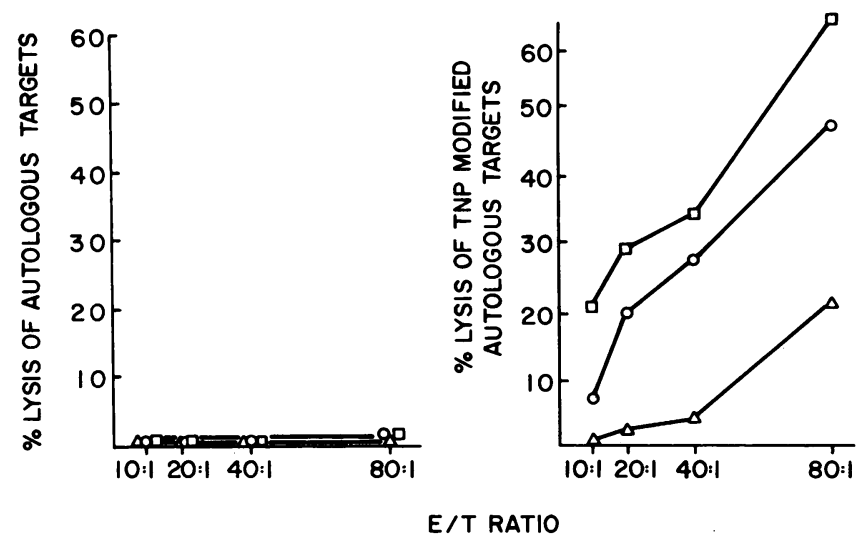

Figure 2. Hapten altered self-reactive CTL generated by $T_{h}$ clone 86 are predominantly $\mathrm{CD4}^{-}, \mathrm{CD8}^{+}$. Responder $\mathrm{T}$ cells were cocultured with $\mathrm{x}$-irradiated, TNP modified, autologous $\mathrm{E}^{-}$stimulators and clone 86 cells. After $6 \mathrm{~d}$, viable cells were recovered and aliquots treated with control antibody (o), OKT4 (), or OKT8 $(\Delta)$ in the presence of complement. Each treatment group was washed extensively and assayed for cytotoxicity against unmodified and TNP modified autologous targets at the E/T ratios indicated. Surface phenotype of cells in each treatment group was as follows: control antibody $\mathrm{CD} 4=42, \mathrm{CD} 8=48 ; \mathrm{T} 4+$ complement $\mathrm{CD} 4=1, \mathrm{CD} 8=97$, $\mathrm{T} 8+$ complement CD4 $=94, \mathrm{CD} 8=5$.
After $6 \mathrm{~d}$, these cells were assayed for cytolytic activity against a panel of target cells, including the natural killer cell (NK) sensitive target cell line K562 and unmodified or TNP-modified cells derived from a panel of HLA haplotype defined allogeneic donors. In addition, CTL specificity was probed by blocking the cytolytic activity of the effector CTL, generated in the presence of the clone $86 \mathrm{~T}_{h}$ cells, with monoclonal antibodies against MHC class I or class II antigens.

As shown in Fig. 3, CTLs generated under these culture conditions lyse TNP modified, but not unmodified, autologous targets and cytolysis is markedly inhibited by preincubating target cells with a monoclonal antibody directed against either a framework determinant on MHC class I molecules (W6/32) or an anti-beta-2 microglobulin specific antibody (NAMB-1). In contrast, antibodies to MHC class II framework determinants (L243) or a polymorphic MHC class I determinant of the HLA-A-2 molecule (CR11-351) or the A3 molecule (GAPA3), are without significant effect.

The inability of GAPA3, which binds to the HLA A-3 molecule expressed on the target cell, to block cytolysis (Fig. 3) suggests that the altered self-reactive CTL induced in this study are directed against other target cell specificities. In this regard, while in all studies the CTL generated preferentially lyse TNP modified autologous targets, these effector cells do lyse, to a significant extent, TNP modified allogeneic targets, which share no serologically defined MHC class I antigens with the CTL donor (Table I). This result is consistent with a previous report demonstrating that a large proportion (40-80\%) of TNP specific human CTL are restricted by nonpolymorphic, species specific determinants, presumably expressed on HLA class I molecules (13).

The study depicted in Fig. 4 demonstrates the striking capacity of clone $86 T_{h}$ cells selectively enhances the generation

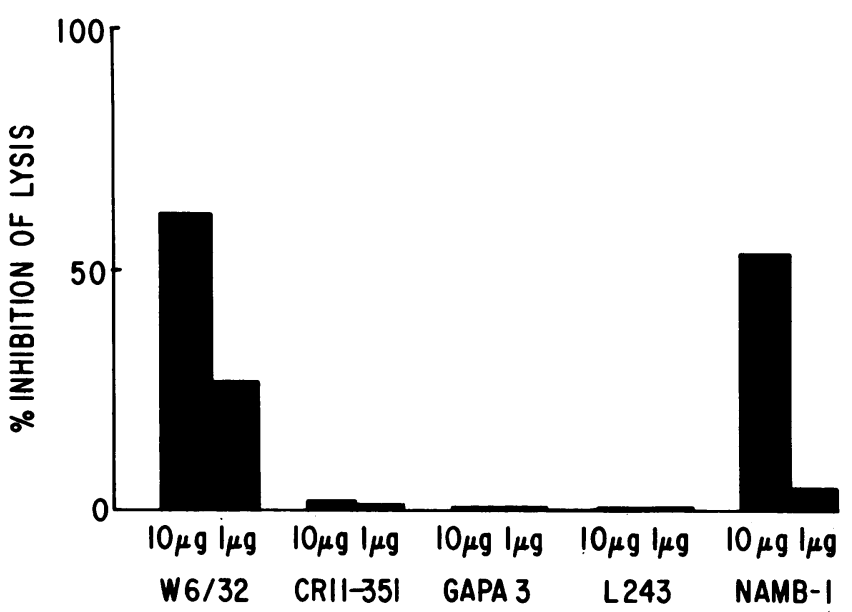

Figure 3. Altered self-reactive CTL generated by $T_{h}$ clone 86 are MHC class I directed. Responder $T$ cells were cultured with $\mathrm{x}$-irradiated, TNP modified, $\mathrm{E}^{-}$autologous stimulators and clone 86 cells. After $6 \mathrm{~d}$, the culture was assayed at an E/T ratio of 60/1 for cytotoxicity against unmodified and TNP modified autologous targets in the presence or absence of the indicated concentration of monoclonal antibody. Percent inhibition is calculated by comparing the percent lysis observed in the presence of antibody to that observed in final medium alone. At an E/T ratio of $60 / 1$, there was $0.5 \%$ lysis of unmodified and $38 \%$ lysis of TNP modified autologous targets in final medium alone. 
Table I. Cytolytic Potential of Altered Self-reactive CTL Induced by Clone $86 T_{h}$ Cells

\begin{tabular}{|c|c|c|c|c|c|}
\hline \multirow{3}{*}{$\begin{array}{l}\text { Description of } \\
\text { target cell }\end{array}$} & \multicolumn{3}{|c|}{ Target cell HLA type } & \multicolumn{2}{|c|}{ Percent lysis of targets } \\
\hline & & & & $\mathrm{E} / \mathrm{T}$ & \\
\hline & A & B & DR & & 10:1 \\
\hline \multicolumn{6}{|l|}{ Exp. 1} \\
\hline A & 3,11 & 8,18 & $1,-$ & 2 & 0 \\
\hline$A_{\mathrm{TNP}}$ & & & & $49(47)$ & $32(32)$ \\
\hline B & 2,11 & 8,32 & 1,3 & 2 & 2 \\
\hline $\mathbf{B}_{\mathrm{TNP}}$ & & & & $40(38)$ & $26(24)$ \\
\hline C & $3,-$ & 7,35 & $1,-$ & 33 & 19 \\
\hline $\mathrm{C}_{\mathrm{TNP}}$ & & & & $24(-)$ & $20(1)$ \\
\hline $\mathrm{D}$ & 2,32 & 35,38 & 2,6 & 42 & 23 \\
\hline $\mathrm{D}_{\mathrm{TNP}}$ & & & & $44(2)$ & $30(7)$ \\
\hline \multicolumn{6}{|l|}{ Exp. 2} \\
\hline $\mathrm{C}$ & $3,-$ & 7,35 & $1,-$ & 0 & 0 \\
\hline $\mathrm{C}_{\mathrm{TNP}}$ & & & & $45(45)$ & $29(29)$ \\
\hline A & 3,11 & 8,18 & $1,-$ & 5 & 7 \\
\hline $\mathbf{A}_{\mathrm{TNP}}$ & & & & $16(11)$ & $13(6)$ \\
\hline E & 3,23 & 44,35 & 2,4 & 8 & 1 \\
\hline $\mathrm{E}_{\mathrm{TNP}}$ & & & & $24(16)$ & $17(16)$ \\
\hline $\mathrm{F}$ & 11,33 & 35,32 & 6 & 0 & 0 \\
\hline $\mathrm{F}_{\mathrm{TNP}}$ & & & & $32(32)$ & $25(25)$ \\
\hline G & $11, w 32$ & w51, - & 2,7 & 5 & 3 \\
\hline $\mathrm{G}_{\mathrm{TNP}}$ & & & & $21(16)$ & $18(15)$ \\
\hline
\end{tabular}

Responder T cells obtained from donor A (Exp. 1) or donor C (Exp. 2) were cocultured with $x$-irradiated TNP modified, $E^{-}$autologous stimulators and clone $86 T_{h}$ cells. After $6 \mathrm{~d}$, cultures were assayed for cytotoxicity against unmodified and TNP modified target cells obtained from the panel of HLA-typed donors shown. Numbers in parentheses represent TNP specific lysis of each target obtained by subtracting the percent lysis on unmodified cells from that observed on TNP modified targets. Note, the HLA type of the donor of clone 86 is $\mathrm{A} 2,3 \mathrm{~B} 12,35 \mathrm{DR} 2,3$.

of hapten altered self-reactive CTL, without increasing NK cell activity. Finally, as shown in Table I, Exp. 1, some allogeneic target cells are lysed regardless of the presence of TNP on their
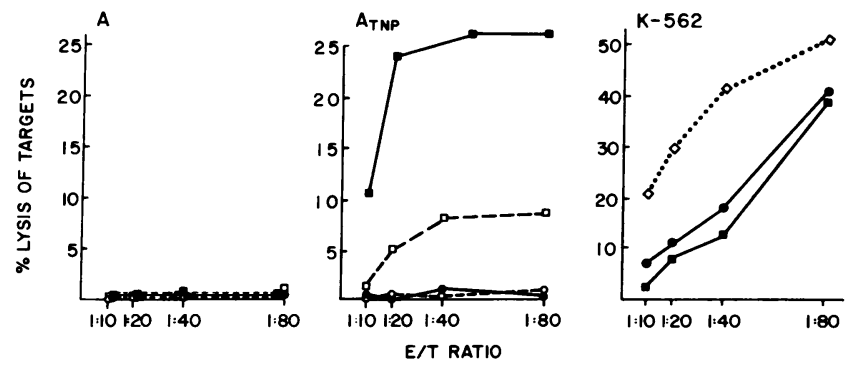

Figure $4 . T_{h}$ clone 86 selectively enhances altered self-reactive CTL, but not NK-like activity. Responder $\mathrm{T}$ cells were cultured with $\mathrm{x}$-irradiated unmodified (open symbols, dashed lines) or TNP modified (closed symbols, solid lines) $\mathrm{E}^{-}$autologous stimulators. Cultures were supplemented with final medium alone $(\circ, \bullet)$ or clone 86 cells $(\square, \bullet)$. After $6 \mathrm{~d}$, cultures were assayed for cytotoxicity against unmodified (A) or TNP modified $\left(\mathrm{A}_{\mathrm{TNP}}\right)$ autologous targets and a NK-sensitive target (K562). Fresh PBL $(\diamond)$ were assayed simultaneously for lysis of K562 cells as a positive NK control. surface. These targets share MHC class I antigens with the donor of clone 86 which the CTL donor does not express. This result suggests that, in addition to the hapten altered self-reactive CTL, a population of CTL are generated against clone 86 . Cold target inhibition studies have confirmed the presence of two distinct CTL populations: hapten altered self-reactive and alloreactive (data not shown). Together, these results demonstrate that: $(a)$ the hapten altered self-reactive CTL generated are MHC class I restricted and exhibit self-preference; $(b)$ clone 86 cells preferentially activate altered self-specific CTL, but do not affect NK cell function; and $(c)$ clone 86 cells are themselves immunogenic. The possibility of a preferential expansion of CTL recognizing determinants expressed on the $T_{h}$ cell surface, at the expense of altered self-reactive CTL, suggests that optimal altered self-CTL responses are to be expected if the responder $T$ cell donor is MHC class I identical with the $T_{h}$ cell donor.

Allospecific $T_{h}$ cell induced altered self-reactive $C T L$ are specific for the sensitizing hapten. Our results suggest, but do not prove, that the CTLs generated in the presence of clone 86 may be specific for the hapten expressed by the autologous stimulator cells present in the sensitization culture. To formally address this issue, responder $\mathrm{T}$ cells were cocultured with either TNP-modified or FITC modified autologous stimulator cells. Cultures were further supplemented with final medium alone or clone $86 \mathrm{~T}_{\mathrm{h}}$ cells. At the end of $6 \mathrm{~d}$, each population was assayed for cytotoxic activity against unmodified, TNP modified, and FITC modified autologous cells. As presented in Table II, the specificity of altered self-reactive CTL induced by clone 86 is dictated by the hapten modified stimulator cells present during culture. Thus, 86 cells enhance TNP specific killing when added to cultures containing TNP modified autologous stimulator cells and FITC specific cytolysis

Table II. Altered Self-reactive CTL Induced by Clone $86 T_{h}$ Cells Are Specific for the Sensitizing Hapten

\begin{tabular}{|c|c|c|c|c|c|c|}
\hline \multirow[b]{3}{*}{ Description of culture } & \multicolumn{6}{|c|}{ \% Lysis of targets } \\
\hline & \multicolumn{2}{|l|}{$\mathbf{A}$} & \multicolumn{2}{|c|}{$\mathbf{A}_{\mathrm{TNP}}$} & \multicolumn{2}{|c|}{$A_{\text {FTTC }}$} \\
\hline & $E / T=60: 1$ & $30: 1$ & $60: 1$ & $30: 1$ & $60: 1$ & $30: 1$ \\
\hline \multicolumn{7}{|l|}{ Exp. 1} \\
\hline $\mathrm{E}^{+}+\mathrm{E}_{\mathrm{TNP}}^{-}$ & 1.7 & $<1$ & 13.2 & $<1$ & 10.6 & 7.0 \\
\hline $\mathrm{E}^{+}+\mathrm{E}_{\mathrm{FTTC}}^{-}$ & 5.2 & $<1$ & 10.2 & 3.8 & 15.2 & 10.5 \\
\hline $\mathrm{E}^{+}+\mathrm{E}_{\overline{\mathrm{TNP}}}^{-}+86$ & 9.8 & 0.7 & 46.6 & 32.7 & 20.5 & 9.2 \\
\hline $\mathrm{E}^{+}+\mathrm{E}_{\mathrm{FTC}}^{-}+86$ & 13.7 & 5.6 & 21.1 & 8.8 & 43.7 & 35.3 \\
\hline \multicolumn{7}{|l|}{ Exp. 2} \\
\hline$E^{+}+E^{-}$ & $<1$ & $<1$ & 9.4 & $<1$ & 3.9 & 5.4 \\
\hline $\mathrm{E}^{+}+\mathrm{E}_{\mathrm{TNP}}^{-}$ & $<1$ & $<1$ & 17.3 & 6.1 & $<1$ & $<1$ \\
\hline $\mathrm{E}^{+}+\mathrm{E}_{\mathrm{FITC}}^{-}$ & $<1$ & $<1$ & 9.8 & $<1$ & 10.3 & 4.4 \\
\hline$E^{+}+E^{-}+86$ & $<1$ & $<1$ & 6.3 & $<1$ & 8.4 & 5.4 \\
\hline $\mathrm{E}^{+}+\mathrm{E}_{\mathrm{TNP}}^{-}+86$ & $<1$ & $<1$ & 50.7 & 24.3 & 8.4 & 5.9 \\
\hline $\mathrm{E}^{+}+\mathrm{E}_{\mathrm{FITC}}^{-}+86$ & $<1$ & $<1$ & 11.2 & 4.6 & 26.9 & 13.3 \\
\hline
\end{tabular}

Responder $\mathrm{T}$ cells were cultured with $\mathrm{x}$-irradiated TNP, FITC, or, in Exp. 2, unmodified $\mathrm{E}^{-}$autologous stimulators in the presence of final medium alone or clone $86 T_{h}$ cells. After $6 \mathrm{~d}$, cultures were assayed for cytotoxicity against unmodified $(A)$, TNP modified $\left(\mathrm{A}_{\mathrm{TNP}}\right)$, or FITC modified $\left(\mathrm{A}_{\mathrm{FTT}}\right)$ autologous target cells at the $\mathrm{E} / \mathrm{T}$ ratios indicated. 
when added to cultures containing FITC modified self-stimulator cells. These results confirm that 86 cells enhance the differentiation and/or proliferation of CTL precursors which have specifically interacted with antigen, i.e., hapten modified autologous cells.

Small numbers of allospecific $T_{h}$ cells are required to amplify altered-self cytolysis and their activity is radioresistant. Having established that allospecific $T_{h}$ cells can amplify the generation of $\mathrm{CD}^{-}, \mathrm{CD}^{+}$hapten altered self-reactive CTLs, we next investigated some of the parameters of cell culture which control this in vitro effect. To this end, we performed experiments in which varying numbers of 86 cells were added at the initiation of cultures containing responder $T$ cells and TNP modified autologous stimulators. After $6 \mathrm{~d}$, the number of viable $T$ cells recovered was determined and their CTL activity was assessed on unmodified and TNP modified autologous targets. As shown in Table III, Exp. 1, as few as $0.1 \%$ of clone 86 cells induce readily detectable levels of altered selfcytolysis, while the presence of only $5 \%$ clone 86 cells induces maximal CTL activity on a per cell basis. We would emphasize, however, that the addition of larger numbers of $T_{h}$ cells, while not increasing the level of cytotoxicity generated at any effector to target ratio, increased by two- to threefold the number of viable effector $T$ cells generated at the end of $6 \mathrm{~d}$ of culture. Therefore, although relatively small numbers of $T_{h}$ cells can induce significant CTL activity, larger numbers amplify the proliferative response of the responder $\mathrm{T}$ cells thereby generate more CTLs during the period of culture.

The capacity of cloned allospecific $T_{h}$ cells to induce $B$ cell proliferation and differentiation into antibody-forming cells is resistant to $\mathrm{x}$-irradiation (21). We were therefore interested to determine the effect of $\mathrm{x}$-irradiation on 86 helper activity for CTL generation. As presented in Table III, Exp. 2, $x$-irradiation of 86 cells before their addition to culture did not diminish the hapten altered self-reactive CTL response induced. These data confirm that proliferation of 86 cells is not required for their helper activity. Moreover, utilizing a monoclonal antiidiotypic antibody (19.1) to the 86 cell $\mathrm{T}$ cell antigen receptor on clone 86 cells, we determined that after $x$-irradiation, viable 86 cells are lost from culture within $36 \mathrm{~h}$ (data not shown). This observation, combined with the accelerated kinetics of altered self-CTL observed in the presence of 86 cells (significant levels of TNP specific killing are detectable by day 3 of culture) suggest that clone 86 cells exert their helper effect(s) on an early stage of CTL generation.

Alloreactive $T_{h}$ cells interact with isolated $C D T 4^{-}, C D T 8^{+}$ responder $T$ cells in the induction of hapten altered self-reactive $C T L$. To determine if clone 86 enhanced altered self-CTL responses require the presence of additional $\mathrm{CD} 4^{+}$helper cells, experiments were performed in which responder $T$ cell populations were depleted of $\mathrm{CD}^{+}$or $\mathrm{CD}^{+}$cells by complementmediated lysis and the resulting populations cocultured with TNP-modified autologous stimulator cells in the presence or absence of 86 cells. Phenotypic analysis of these responder populations was performed to assure that the relevant $T$ cell subset had been depleted. The results of a representative experiment (Fig. 5) demonstrate that $\mathrm{CD}^{+}$cells, cultured either in the presence or absence of clone 86 cells mediate very weak cytolytic activity against TNP modified autologous targets. Similarly, in the absence of clone $86, \mathrm{CD}^{+}$responder cells are relatively inefficient mediators of hapten altered self-cytolysis. In contrast, when $\mathrm{CD}^{+}$responder cells are cocultured with

Table III. Small Numbers of Clone $86 T_{h}$ Cells Are Required to Amplify Altered Self-cytolysis

\begin{tabular}{|c|c|c|c|c|c|c|c|}
\hline \multicolumn{8}{|c|}{ \% Lysis of TNP modified autologous targets } \\
\hline Responder & $\mathrm{X}$-irradiated stimulator & Clone $86 \mathrm{~T}_{\mathrm{h}}$ cells & $\begin{array}{l}\text { No. or cells recovered } \\
\text { on day } 6\end{array}$ & $\mathrm{E} / \mathrm{T} 80: 1$ & $40: 1$ & $20: 1$ & $10: 1$ \\
\hline $\mathrm{E}^{+}$ & $\mathrm{E}_{\mathrm{TNP}}^{-}$ & - & $3.0 \times 10^{6}$ & 4 & $<1$ & $<1$ & $<1$ \\
\hline $\mathrm{E}^{+}$ & $\mathrm{E}_{\mathrm{TNP}}^{-}$ & $1 \times 10^{2}$ & $3.0 \times 10^{6}$ & 24 & 12 & 10 & 9 \\
\hline $\mathrm{E}^{+}$ & $\mathrm{E}_{\mathrm{TNP}}^{-}$ & $1 \times 10^{3}$ & $3.4 \times 10^{6}$ & 30 & 17 & 14 & 11 \\
\hline $\mathbf{E}^{+}$ & $\mathbf{E}_{\mathbf{T N P}}^{-}$ & $5 \times 10^{3}$ & $5.7 \times 10^{6}$ & 42 & 24 & 20 & 17 \\
\hline $\mathrm{E}^{+}$ & $\mathrm{E}_{\mathrm{TNP}}^{-}$ & $1 \times 10^{4}$ & $6.6 \times 10^{6}$ & 43 & 31 & 24 & 20 \\
\hline $\mathrm{E}^{+}$ & $\mathbf{E}_{\mathrm{TNP}}^{-}$ & $5 \times 10^{4}$ & $9.0 \times 10^{6}$ & 45 & 32 & 23 & 19 \\
\hline
\end{tabular}

Exp. 2

\begin{tabular}{|c|c|c|c|c|c|}
\hline \multirow[b]{2}{*}{ Responder } & \multicolumn{2}{|c|}{ Description of culture } & \multicolumn{3}{|c|}{ \% Lysis of TNP modified targets } \\
\hline & $\mathrm{X}$-irradiated stimulator & $T_{b}$ clone & $E / T=40: 1$ & $20: 1$ & $10: 1$ \\
\hline $\mathrm{E}^{+}$ & $\mathbf{E}^{-}$ & - & 0 & 0 & 1 \\
\hline $\mathrm{E}^{+}$ & $\mathrm{E}_{\mathrm{TN} P}^{-}$ & - & 7 & 5 & 3 \\
\hline $\mathrm{E}^{+}$ & $\mathbf{E}^{-}$ & 86 & 4 & 4 & 2 \\
\hline $\mathrm{E}^{+}$ & $\mathrm{E}_{\mathrm{TNP}}^{-}$ & 86 & 26 & 17 & 14 \\
\hline $\mathrm{E}^{+}$ & $\mathrm{E}_{\mathrm{TNP}}^{-}$ & $86(500 r)$ & 20 & 16 & 11 \\
\hline $\mathrm{E}^{+}$ & $\mathrm{E}_{\mathrm{TNP}}^{-}$ & $86(2,000 r)$ & 32 & 25 & 17 \\
\hline
\end{tabular}

(Exp. 1) $2 \times 10^{5}$ responder T cells were cultured with $1 \times 10^{5} \mathrm{x}$-irradiated, TNP modified, $\mathrm{E}^{-}$autologous stimulators in the presence of final medium or varying numbers of clone $86 \mathrm{~T}_{\mathrm{h}}$ cells. After $6 \mathrm{~d}$, cultures were counted and assayed for cytotoxicity against TNP modified autologous targets at the E/T ratio indicated. (Exp. 2) Responder T cells were cultured with $x$-irradiated unmodified or TNP modified $E^{-}$autologous stimulators. Cultures were supplemented with final medium or $1 \times 10^{4}$ clone 86 cells, which were either untreated (86) or $x$-irradiated with 500 or 2,000 rad as indicated. After $6 \mathrm{~d}$, cultures were harvested and assayed for cytotoxicity against TNP modified autologous target cells. 


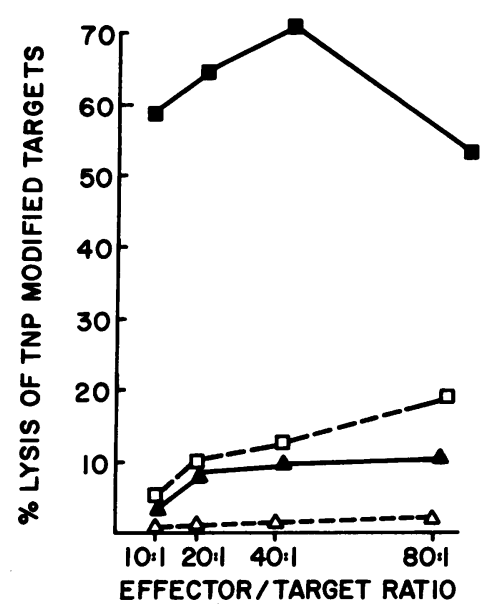

Figure 5. $\mathrm{T}_{\mathrm{h}}$ clone 86 can interact directly with $\mathrm{CD4}^{-}, \mathrm{CD8}^{+} \mathrm{CTL}^{\text {precur- }}$ sors to enhance altered selfcytolysis. Responder T cells were subjected to complement-mediated lysis in the presence of anti-CD4 $(\square, \square)$ or anti-CD8 $(\Delta, \Delta)$, washed, and cultured with $\mathrm{x}$-irradiated, TNP modified $\mathrm{E}^{-}$ autologous stimulators in final medium alone (open symbols, dotted lines) or in the presence of clone $86 \mathrm{~T}_{\mathrm{h}}$ cells (closed symbols, solid lines). After $6 \mathrm{~d}$, cultures were assayed for cytotoxicity against TNP-modified autologous targets at the E/T ratios shown. Surface phenotype of cells in each treatment group was as follows: anti-CD4 + C CD4 = 0, CD8 $=95$; ani-CD8 + C CD4 $=94$, CD8 $=5$.

TNP-modified autologous stimulators and $86 T_{h}$ cells, extremely high levels of cytolytic activity are demonstrable against the TNP modified autologous target. This result is consistent with our previous demonstration that optimal hapten altered self-cytolysis required $\mathrm{CD}^{+}$cell interaction with $\mathrm{CD}^{+}$CTL precursors (11). Taken together, these results suggest that the interaction of antigen activated CTL precursors with 86 cells, or their soluble products, is sufficient for the induction of hapten altered self-cytolysis with no requirement for additional $\mathrm{CD}^{+}$helper cells.

Allospecific $T_{h}$ clone 86 preferentially activates $C D 8^{+}$cells. Amplification of altered self-reactive CTL responses by both isolated $\mathrm{CD}^{+}$cells and unselected $\mathrm{T}$ cells, in the absence of enhanced NK cell activity, suggested that clone 86 may preferentially activate $\mathrm{CD} 8^{+} \mathrm{CTL}$ precursors. To investigate this point, cultures containing unselected responder $T$ cells and $\mathrm{x}$-irradiated unmodified or TNP modified autologous stimula- tors were supplemented with final medium alone or $\mathrm{x}$-irradiated clone 86 cells. Cultures were assayed, over time, for $T$ cell subset composition, $T$ cell number, and cytolytic activity. Two representative experiments, Table IV, demonstrate that 86 cells induce a reversal of the normal CD4 to CD8 ratio, such that after $6 \mathrm{~d}$ of culture $>50 \%$ of the recovered cells are $\mathrm{CD}^{+}$. Moreover, after a week of expansion in the presence of IL-2, the proportion of $\mathrm{CD}^{+}$cells increases to $>80 \%$. Perhaps most important, the $\mathrm{CD}^{+}$cells induced in the presence of clone 86 cells are readily expanded in vitro, to yield large numbers of highly efficient hapten altered self-reactive CTL (Fig. 6).

Allospecific $T_{h}$ cells amplify altered self-cytolysis via lymphokine production. Two pieces of data suggest that clone 86 may secrete lymphokines that trigger CTL precursor differentiation and/or proliferation. First, as shown in Fig. 3, very small numbers $(0.1 \%)$ of clone 86 cells can markedly amplify altered self-CTL responses. Second, in our previous study (8), we reported that 86 cells induced an allospecific CTL response against $\mathrm{DR} 1^{-}$allogeneic stimulators providing a $\mathrm{DR} 1^{+}$stimulator was also present in culture. These "three-party" experiments were most consistent with the release of lymphokines by antigen (DR1)-activated clone 86 cells, which enhanced CTL activity of precursors that recognize MHC class I determinants on the $\mathrm{DR} 1^{-}$stimulator.

To formally address the role of clone 86 derived lymphokines, 86 cells were cultured with final medium alone, $\mathrm{DR}^{+}$, or $\mathrm{DR}^{-} \mathrm{x}$-irradiated, $\mathrm{E}^{-}$stimulators. Additional cultures contained 86 cells, $\mathrm{DR}^{-}{ }^{-}$stimulators and an antibody against a private idiotype of the T cell receptor expressed by clone 86 . After $36 \mathrm{~h}$, the supernatants were harvested, assayed for lymphokine content, and added to cultures containing responder T cells and hapten-altered autologous stimulators. As shown in Table V, 86 cells, activated by antigen or antiidiotypic antibody, produce quantities of IL-4 that are maximally active in the CD23 induction bioassay, but levels of IL-2 that are barely detectable. In two separate experiments (Table VI), supernatants derived from antigen-activated clone 86 cells effectively

Table IV. Cloned $86 T_{h}$ Cells Enhance the In Vitro Expansion of $C D 8^{+} T$ Cells

\begin{tabular}{|c|c|c|c|c|c|c|c|c|}
\hline \multirow{2}{*}{\multicolumn{3}{|c|}{ Description of culture }} & \multicolumn{6}{|c|}{ Kinetic analysis of $\mathrm{T}$ cell subset composition } \\
\hline & & & \multicolumn{2}{|c|}{ day 4} & \multicolumn{2}{|c|}{ day 7} & \multicolumn{2}{|c|}{ day 15} \\
\hline Responder & $\begin{array}{l}\text { X-irradiated } \\
\text { stimulator }\end{array}$ & $\begin{array}{l}T_{h} \text { clone } \\
86 \text { cells }\end{array}$ & CD4 & CD8 & CD4 & CD8 & CD4 & CD8 \\
\hline \multicolumn{9}{|l|}{ Exp. 1} \\
\hline $\mathbf{E}^{+}$ & $\mathbf{E}^{-}$ & - & 66 & 27 & 67 & 26 & 79 & 11 \\
\hline $\mathrm{E}^{+}$ & $\mathbf{E}_{\mathbf{T N P}}^{-}$ & - & 65 & 23 & 74 & 23 & 74 & 15 \\
\hline $\mathrm{E}^{+}$ & $\mathbf{E}^{-}$ & + & 64 & 25 & 47 & 52 & 13 & 81 \\
\hline $\mathrm{E}^{+}$ & $\mathrm{E}_{\mathrm{TNP}}^{-}$ & + & 66 & 20 & 48 & 50 & 17 & 78 \\
\hline \multicolumn{9}{|l|}{ Exp. 2} \\
\hline $\mathbf{E}^{+}$ & $\mathbf{E}^{-}$ & - & NT & NT & 57 & $32\left(7 \times 10^{6}\right)$ & 83 & $18\left(17 \times 10^{6}\right)$ \\
\hline $\mathrm{E}^{+}$ & $\mathbf{E}_{\mathrm{TNP}}^{-}$ & - & NT & NT & 60 & $40\left(7 \times 10^{6}\right)$ & 66 & $40\left(12 \times 10^{6}\right)$ \\
\hline $\mathbf{E}^{+}$ & $\mathbf{E}^{-}$ & + & NT & NT & 33 & $57\left(14 \times 10^{6}\right)$ & 17 & $72\left(46 \times 10^{6}\right)$ \\
\hline $\mathbf{E}^{+}$ & $\mathrm{E}_{\mathrm{T} N P}^{-}$ & + & NT & NT & 28 & $70\left(14 \times 10^{6}\right)$ & 5 & $90\left(54 \times 10^{6}\right)$ \\
\hline
\end{tabular}

Responder $\mathrm{T}$ cells were cultured with unmodified or TNP modified $\mathrm{x}$-irradiated $\mathrm{E}^{-}$autologous stimulators in the presence of final medium alone or clone $86 T_{h}$ cells. After day 7, cultures were expanded in the presence of IL-2. At the time points indicated, aliquots of these populations were analyzed for CD4 and CD8 composition. Numbers in parentheses represent total number of viable $T$ cells recovered from an initial responder T cell population of $4.8 \times 10^{6}$. Note, the cytotoxic activity of group 4, Exp. 2, assayed on day 6 and day 16 is depicted in Fig. 6 . 


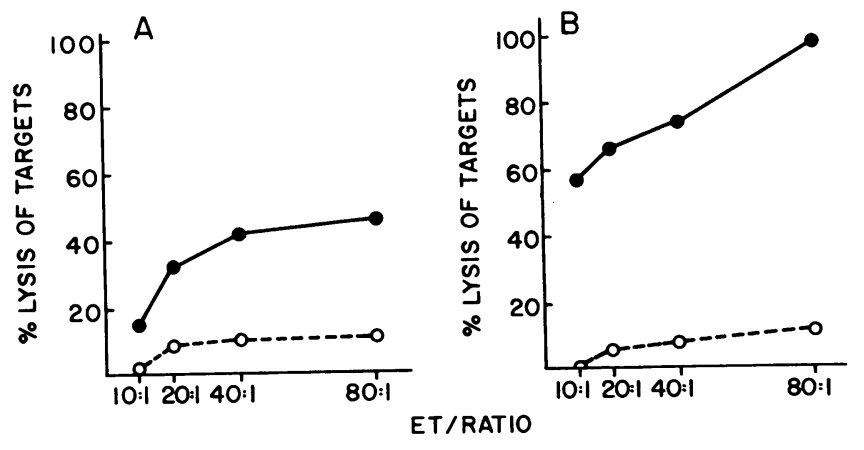

Figure 6. Hapten altered self-reactive CTL, generated by clone $86 T_{h}$ cells, maintain efficient, specific lysis after expansion in the presence of IL-2. Responder T cells cultured with TNP modified, $\mathrm{E}^{-}$autologous stimulators and clone $86 T_{h}$ cells were assayed for cytotoxicity against unmodified $(0)$ or TNP modified $(\bullet)$ autologous targets after $6 \mathrm{~d}$ of primary in vitro sensitization $(A)$ or after $10 \mathrm{~d}$ of growth in the presence of IL-2 $(B)$.

trigger hapten-altered self-cytolysis, provided TNP modified autologous stimulators were also present in culture. Of interest, rIL-4, in concentrations that exceed those present in clone 86 culture supernatants, is a much less efficient trigger of altered self cytolysis. Together, these results suggest that clone 86 provides help for CTL precursors, at least in part, by the antigen induced release of soluble mediators. Although IL-4 may play an important role in this effect, it appears likely that additional lymphokines, as yet unidentified, are also involved.

Table V. Antigen Activated Clone $86 T_{h}$ Cells Produce IL-4 but Little IL-2

\begin{tabular}{|c|c|c|}
\hline Source of lymphokines & $\begin{array}{l}\text { \% CD23 bearing } \\
\text { B cells }\end{array}$ & $\begin{array}{l}{\left[{ }^{3} \mathrm{H}\right] \mathrm{TdR} \text { incorporation }} \\
\text { by CTLL- } 2 \text { cells }\end{array}$ \\
\hline None & 8 & 587 \\
\hline rIL-4 $20 \mathrm{U}$ & 47 & NT \\
\hline rIL-4 $5 \mathrm{U}$ & 45 & NT \\
\hline rIL-4 $0.5 \mathrm{U}$ & 30 & NT \\
\hline IL-2 $160 \mathrm{U}$ & NT & 10,248 \\
\hline IL-2 $80 \mathrm{U}$ & NT & 4,589 \\
\hline IL-2 $16 \mathrm{U}$ & NT & 2,819 \\
\hline IL-2 $1.6 \mathrm{U}$ & NT & 1,073 \\
\hline$(86+$ medium $)$ sup 1 & 12 & 457 \\
\hline$\left(86+D R 1_{x r}^{+}\right) \sup 2$ & 43 & 912 \\
\hline$\left(86+D R 1_{x r}^{-}\right) \sup 3$ & 10 & 488 \\
\hline$\left(86+D R 1_{x r}^{-}+\right.$anti-19.1) sup 4 & 45 & 1,628 \\
\hline
\end{tabular}

36-h culture supernatants (sup) were isolated from clone $86 T_{h}$ cells cultured with medium alone (sup 1), $\mathrm{x}$-irradiated, $\mathrm{E}^{-}$stimulators obtained from a $\mathrm{DR}^{+}(\sup 2)$ or a $\mathrm{DR}^{-}(\sup 3)$ donor, or $\mathrm{DR}^{-}$stimulators in concert with $1 \mu \mathrm{g} / \mathrm{ml}$ of anti-19.1 antibody (sup 4). Supernatants were assayed at a final concentration of $30 \%$ for IL- 4 and IL- 2 bioactivity. IL- 4 was assessed by the capacity to induce the expression of CD23 on resting human B cells, while IL-2 was detected by the induction of proliferation by the murine T cell line, CTLL-2. Note, in preliminary experiments, we confirmed that IL-2 is without activity in the CD-23 assay and rIL-4 does not support CTLL-2 cell proliferation.
Table VI. Clone $86 T_{h}$ Cells Enhance Altered Self-cytolysis by Release of Soluble Factor(s)

\begin{tabular}{|c|c|c|c|c|c|c|}
\hline \multicolumn{3}{|c|}{ Description of culture } & \multicolumn{4}{|c|}{$\begin{array}{l}\text { \% Lysis of TNP modified } \\
\text { autologous targets }\end{array}$} \\
\hline Responder & $\begin{array}{l}\text { X-irradiated } \\
\text { stimulator }\end{array}$ & $\begin{array}{l}\text { Helper } \\
\text { stimulus }\end{array}$ & $\mathrm{E} / \mathrm{T}=$ & $80: 1$ & $40: 1$ & $20: 1$ \\
\hline \multicolumn{7}{|l|}{ Exp. 1} \\
\hline $\mathrm{E}^{+}$ & $\mathrm{E}^{-}$ & - & & 3 & 0 & 0 \\
\hline $\mathrm{E}^{+}$ & $\mathrm{E}_{\mathrm{TNP}}^{-}$ & - & & 2 & 0 & $\mathbf{0}$ \\
\hline $\mathrm{E}^{+}$ & $\mathrm{E}^{-}$ & 86 & & 8 & 2 & 3 \\
\hline $\mathrm{E}^{+}$ & $\mathbf{E}_{\mathrm{TNP}}^{-}$ & 86 & & 19 & 12 & 9 \\
\hline $\mathrm{E}^{+}$ & $\mathrm{E}_{\mathrm{TNP}}^{-}$ & sup 1 & & 9 & 0 & 2 \\
\hline $\mathbf{E}^{+}$ & $\mathrm{E}_{\mathrm{TNP}}^{-}$ & $\sup 2$ & & 28 & 17 & 11 \\
\hline $\mathrm{E}^{+}$ & $E_{\mathrm{TNP}}^{-}$ & sup 3 & & 19 & 10 & 8 \\
\hline \multicolumn{7}{|l|}{ Exp. 2} \\
\hline $\mathrm{E}^{+}$ & $\mathrm{E}^{-}$ & & & 11 & 12 & 0 \\
\hline $\mathbf{E}^{+}$ & $\mathrm{E}_{\mathrm{TNP}}^{-}$ & & & 22 & 14 & 0 \\
\hline $\mathrm{E}^{+}$ & $\mathrm{E}_{\mathrm{TNP}}^{-}$ & 86 & & 6 & 5 & 0 \\
\hline $\mathrm{E}^{+}$ & $\mathrm{E}_{\mathrm{TNP}}^{-}$ & 86 & & 53 & 36 & 5 \\
\hline $\mathrm{E}^{+}$ & $\mathrm{E}_{\mathrm{TNP}}^{-}$ & sup 2 & & 41 & 32 & 11 \\
\hline $\mathbf{E}^{+}$ & $\mathrm{E}_{\mathrm{TNP}}^{-}$ & rIL-4 (20 U) & & 21 & 16 & 3 \\
\hline
\end{tabular}

Responder T cells were cultured with unmodified or TNP modified, $\mathrm{x}$-irradiated, $\mathrm{E}^{-}$autologous stimulators. Cultures were supplemented with final medium, clone $86 T_{h}$ cells, or $30 \%$ final concentration of culture supernatants obtained from $86 T_{h}$ cell cultures as described in the legend to Table VI. In Exp. 2, a culture was supplemented with $20 \mathrm{U}$ per microwell of rIL-4. Note, while clone 86 cells were added at the initiation of culture, clone $T_{h}$ cell culture supernatants and rIL- 4 were added $24 \mathrm{~h}$ after the initiation of culture.

\section{Discussion}

The at least partial success of lymphokine-activated killer (LAK) cells in the treatment of advanced solid tumors (27) has served to focus attention on the potential of adoptive immunotherapy for human disease. While the majority of LAK cells mediate NK-like activity, it has been recently demonstrated that high doses of IL-2 also induce tumor antigen specific, MHC class I-restricted CTL that are crucial for the elimination of macrometastases in several experimental models of tumor immunity $(28,29)$.

With these issues in mind, we asked if cloned, alloantigen reactive human $T_{h}$ cells might be exploited in the development of more specific adoptive immunotherapy in man. As a first step, we have examined the effect of one such clone, the DR 1 reactive $T_{h}$ clone termed 86 , on an in vitro model of tumor immunity, the induction of altered self-reactive CTL. The studies presented here demonstrate that the addition of small numbers of clone 86 cells to sensitization cultures containing responder $\mathrm{T}$ cells and hapten modified autologous stimulators, efficiently enhances the in vitro generation of altered self-reactive CTL. The killer cells induced belong to the $\mathrm{CD}^{-}, \mathrm{CD}^{+} \mathrm{T}$ cell subset and their cytolytic activity is specific for hapten in association with self MHC class I antigens. The generation of CTL requires the presence of both clone 86 cells and hapten modified autologous stimulators during in vitro sensitization, and the CTL that result are specific for the hapten (either TNP or FITC) expressed on the autologous stimulator cells. In all studies, the CTL generated lyse hapten-modified autologous 
targets more efficiently than hapten-modified allogeneic targets, and cytolytic activity is efficiently and selectively inhibited by treating target cells with antibodies against monomorphic determinants MHC class I molecules. Finally, the CD8 ${ }^{+}$ altered self-reactive CTL induced by clone 86 are readily expanded in the presence of IL-2 with maintenance of specific cytotoxic activity.

Several aspects of our data suggest that clone 86 may preferentially activate $\mathrm{CD}^{+}$cells. First, altered self-reactive CTL are efficiently induced in cultures containing hapten-modified stimulators, clone 86 cells, and purified $C D 8^{+}$responder $\mathrm{T}$ cells. Second, even in the presence of small numbers of clone 86 cells, $\mathrm{CD}^{+}$cells are selectively expanded during the period of primary in vitro sensitization and subsequent growth in IL-2. Third, clone 86 cells selectively enhance hapten-altered self-specific cytolysis, but not NK cell activity. Taken together, these results demonstrate that allospecific $T_{h}$ cells can enhance the proliferation and/or differentiation of "classic" $\mathrm{CD}^{+}$altered self-reactive CTL precursors that have interacted with antigen.

While NK cells are not induced by clone 86 , we would emphasize that our data do not rule out activation of at least a subset of $\mathrm{CD}^{+}$cells. In this regard, there is evidence in the murine system to suggest that IL- 4 serves as an autocrine, selectively enhancing the growth of IL-4 producing $T_{h}$ cells (30). Our demonstration of significant IL-4 production by activated clone 86 cells raises the intriguing possibility that under the culture conditions employed, this $T_{h}$ clone may trigger the outgrowth of $\mathrm{CD4}^{+} \mathrm{T}_{h}$ cells of the same functional subclass as clone 86 , but specific for modified self, e.g., hapten-modified autologous MHC class II molecules. To this end, we are currently analyzing the function and antigen specificity of $\mathrm{CD}^{+}$ responder $\mathrm{T}$ cells that have been cultured with hapten-modified autologous stimulators and clone 86 cells.

The capacity of small numbers of clone 86 cells to trigger altered self-cytolysis suggested that these cells may function, at least in part, by the release of lymphokines. To address this point, 86 cells were activated with antigen $\left(D R 1^{+}\right.$stimulator cells) or antiidiotypic antibody, supernatants assayed for lymphokine content and the capacity to induce altered self-reactive CTL. Our data confirm that clone 86 cells elaborate soluble mediators which can support the generation of hapten altered self-reactive CTL. Of interest, the supernatants that were most efficient in CTL generation contained only trace amounts of IL-2, but substantial amounts of IL-4. These results suggest that clone 86 may represent a human equivalent of the murine $T_{h} 2$ subset, described by Mosman et al., which preferentially secretes IL-4 and IL-5, but little IL-2 or INFgamma (10). Moreover, the possibility that clone 86 may amplify altered self-cytolysis, at least in part, by production of IL-4 is in agreement with a recent report by Widmer et al. documenting the capacity of recombinant (r) IL-4 to enhance allospecific CTL responses by human peripheral blood $T$ cells without amplifying LAK cell activity (31). In this context, our results extend the studies of Widmer et al., demonstrating that IL-4 producing human $T_{h}$ cells can activate purified $C D 8^{+}$ CTL precursors and can enhance a physiologically relevant response, altered self-cytolysis.

It should be noted, however, that lymphokines other than IL-2 and IL-4 can trigger CTL differentiation. Thus, another product of $T_{h} 2$ cells, IL-5, induces antigen-activated murine thymocytes to differentiate into specific CTL (32). In addition, a novel human lymphokine with CTL activating properties has recently been described (33). These considerations, coupled with the failure of equivalent quantities of rIL-4 to substitute for 86 derived supernatants in the induction of alteredself cytolysis, suggest that clone 86 may represent a subset of $T_{h}$ cells that elaborates a combination of lymphokines, acting in concert, to optimize CTL responses.

While the importance of lymphokines in CTL activation is clear, it should be emphasized that lymphokines may not represent true "hormones" of the immune system, acting at great distances from their site of production. Rather, these molecules are likely to function locally to amplify the response of antigen-activated lymphocytes in close proximity to the lymphokine-secreting cell (34). For this reason, the positive effect of clone 86 derived lymphokines, readily detected in our in vitro model of altered self-cytolysis, is likely to be lost in the in vivo situation. These considerations, combined with the intriguing possibility of antigen binding and presentation by activated $T_{h}$ cells $(18,19)$, suggest a novel strategy for antigen specific adoptive immunotherapy in which $T_{h}$ cells, rather than their soluble products, are employed. For example, it may be possible to "arm" $T_{h}$ cells like clone 86 , utilizing cell membrane fragments or liposomes, which contain both tumor antigen modified MHC class I molecules and MHC class II antigen recognized by the $T_{h}$ cell. Binding of these membrane fragments or liposomes to the $T$ cell receptor may both activate the $T_{h}$ cells to produce lymphokines and permit the $T_{h}$ cell to function as an antigen presenting cell. Upon in vivo transfer, these cells may serve to bring into close proximity, altered self-specific CTL precursors, altered self antigen, and $T_{h}$ cells, which function to amplify the differentiation and proliferation of CTL precursors that have interacted with antigen. Further, the use of alloreactive, rather than tumor antigen specific, $T_{h}$ cells is appealing, as these cells are relatively easy to isolate and propagate in vitro. From a theoretical standpoint, alloreactive $T_{h}$ cells may also have the advantage of bypassing the potential inhibitory effects of tumor antigen-specific suppressor cells that have been shown to downregulate effective tumor rejection in several experimental models of tumor specific immunity (7).

\section{Acknowledgments}

The authors wish to thank Ms. Venus Te Eng Fo for careful preparation of this manuscript.

This work was supported in part by National Institutes of Health grants AI-18263 (awarded to Steven M. Friedman), U. S. Public Health Service grants CA-38407 and CA-30469 (awarded to Carlo Russo), grant CA-42046 and an Investigator Award of the Cancer Research Institute (awarded to David N. Posnett), grant KO 8 AM-01523 and an Arthritis Foundation Investigator Award (awarded to Mary K. Crow).

\section{References}

1. Lukacher, A. E., V. L. Brachiale, and T. J. Brachiale. 1984. In vivo effector function of influenza virus-specific cytotoxic $\mathrm{T}$ lymphocyte clones is highly specific. J. Exp. Med. 160:814-826.

2. Byrne, J. A., and M. B. A. Oldstone. 1984. Biology of cloned cytotoxic $\mathrm{T}$ lymphocytes specific for lymphocyte choriomeningitis virus: clearance of virus in vivo. J. Virol. 51:682-686. 
3. Fernandez-Cruz, E., B. Halliburton, and J. D. Feldman. 1979. In vivo elimination by specific effector cells of an established syngeneic rat Moloney virus-induced sarcoma. J. Immunol. 123:1772-1777.

4. Cheever, M. A., P. D. Greenberg, and A. Fefer. 1981. Specific adoptive therapy of established leukemia with syngeneic lymphocytes sequentially immunized in vivo and in vitro and nonspecifically expanded by culture with interleukin 2 . J. Immunol. 126:1318-1322.

5. Cheever, M. A., D. B. Thompson, J. P. Klarnet, and P. D. Greenberg. 1986. Antigen-driven long-term cultured T cells proliferate in vivo, distribute widely, mediate specific tumor therapy, and persist long term as functional memory T cells. J. Exp. Med. 163:1100-1112.

6. Greenberg, P. D., M. A. Cheever, and A. Fefer. 1981. Eradication of disseminated murine leukemia by chemoimmunotherapy with cyclophosphamide and adoptively transferred immune syngeneic Ly-1 ${ }^{+}$,2-lymphocytes. J. Exp. Med. 154:952-963.

7. North, R. J. 1985. Downregulation of anti-tumor immunity. Adv. Cancer Res. 45:1-44.

8. Friedman, S. M., and G. S. Thompson. 1983. Functional restricted, allospecific, human helper $\mathrm{T}$ cell lines that amplify either B cell or cytolytic T cell responses. J. Exp. Med. 157:1675-1680.

9. Arthur, R. P., and D. Mason. 1986. T cells that help B cell responses to soluble antigen are distinguishable from those producing IL-2 on mitogenic or allogeneic stimulation. J. Exp. Med. 163:774786.

10. Mosmann, T. R., H. Cherwinski, M. W. Bond, M. A. Giedlin, and R. L. Coffman. 1986. Two types of murine helper T cell clone. I. Definition according to profiles of lymphokine activities and secreted proteins. J. Immunol. 136:2348-2357.

11. Friedman, S. M., S. B. Hunter, O. H. Irigoyen, P. C. Kung, G. Goldstein, and L. Chess. 1981. Functional analysis of human T cell subsets defined by monoclonal antibodies. II. Collaborative T-T interaction in the generation of TNP-altered-self reactive cytotoxic T lymphocytes. J. Immunol. 126:1702-1705.

12. Shearer, G. M., T. G. Rehn, and A. M. Schmitt-Verhulst. 1976. Role of mouse major histocompatibility complex in the specificity of in vitro $\mathrm{T}$ cell-mediated lympholysis against chemically-modified autologous lymphocytes. Transplant. Rev. 29:222-248.

13. Shaw, S., D. L. Nelson, and G. M. Shearer. 1978. Human cytotoxic response in vitro to trinitrophenyl-modified autologous cells. I. T cell recognition of TNP in association with widely shared antigens. J. Immunol. 121:281-289.

14. Fyfe, D. A., and J. H. Finke. 1979. Soluble helper factor(s) participates in the generation of cell-mediated cytotoxicity against syngeneic tumor cells. J. Immunol. 122:1156-1161.

15. Tanaka, K., H. Hayashi, C. Hamada, G. Khoury, and G. Jay. 1986. Expression of major histocompatibility complex class I antigens as a strategy for the potentiation of immune recognition of tumor cells. Proc. Natl. Acad. Sci. USA. 83:8723-8727.

16. Hui, K., F. Grosveld, and H. Festenstein. 1985. Rejection of transplantable AKR leukemia cells following MHC DNA-mediated cell transformation. Nature (Lond.). 311:750-752.

17. Zinkernagel, R. M., and P. C. Doherty. 1979. MHC-restricted cytotoxic $T$ cells: studies on the biological role of polymorphic major transplantation antigens determining $T$-cell restriction specificity, function, and responsiveness. Adv. Immunol. 27:51-89.

18. Janeway, C. A., Jr., P. J. Conrad, E. A. Lerner, J. Babich, P. Wettstein, and D. B. Murphy. 1984. Monoclonal antibodies specific for Ia glycoproteins raised by immunization with activated T cells: Possible role of $\mathrm{T}$ cell bound Ia antigens as targets of immunoregulatory T cells. J. Immunol. 132:662-667.

19. Nagy, Z., B. E. Elliott, M. Nabholz, P. H. Krammer, and B.
Pernis. 1976. Specific binding of alloantigens to T cells activated in the mixed lymphocyte reaction. J. Exp. Med. 143:648-659.

20. Friedman, S. M., N. Neyhard, and L. Chess. 1978. Cell-mediated lympholysis of trinitrophenyl derivitized autologous human cells: in vitro triggering by nonspecific signals. J. Immunol. 120:630637.

21. Friedman, S. M., G. S. Thompson, and M. A. Principato. 1982. Allospecific human $T$ cell lines and clones which mediate HLA-DR-restricted helper activity. J. Immunol. 129:2451-2457.

22. Friedman, S. M., O. Irigoyen, J. Kuhns, and L. Chess. 1979. Cell-mediated lympholysis of fluorescein isothiocyanate-conjugated autologous human cells: evidence for hapten specific altered-self reactive human cytotoxic T lymphocytes. J. Immunol. 123:496-500.

23. Barnstable, C. J., W. F. Bodmer, G. Brown, G. Galfre, C. Milstein, A. F. Williams, and A. Ziegler. 1978. Production of monoclonal antibodies to group A erythrocytes, HLA, and other human cell surface antigens-New tools for genetic analysis. Cell. 14:9-20.

24. Russo, C., A. Ng, M. A. Pellegrino, and S. Ferrone. 1983. The monoclonal antibody CR11-351 discriminates HLA-A-2 variants identified by $\mathrm{T}$ cells. Immunogenet. 18:23-35.

25. Gillis, S., M. M. Ferm, W. Ou, and K. A. Smith. 1978. T cell growth factor: parameters of production and a quantitative microassay for activity. J. Immunol. 120:2027-2032.

26. Defrance, T., J. P. Aubry, F. Rousset, B. Vanbervliet, J. Y. Bonnefoy, N. Arai, Y. Takebe, T. Yokota, F. Lee, K. Arai, J. de Vries, and J. Banchereau. 1987. Human recombinant IL-4 induces Fc receptors (CD23) on normal human B lymphocytes. J. Exp. Med. 165:1459-1467.

27. Rosenberg, S. A., M. T. Lotze, L. M. Muul, A. E. Chang, F. P. Avis, S. Leitman, W. M. Linehan, C. N. Robertson, R. E. Lee, J. T. Rubin, C. A. Seipp, C. G. Simpson, and D. E. White. 1987. A progress report on the treatment of 157 patients with advanced cancer using lymphokine activated killer cells and interleukin- 2 or high dose interleukin-2 alone. N. Engl. J. Med. 316:889-894.

28. Mule, J. J., J. C. Yang, S. Shu, R. Lafreniere, and S. A. Rosenberg. 1987. Identification of cellular mechanisms operational in vivo during the regression of established pulmonary metastases by the systemic administration of high dose recombinant interleukin-2. J. Immunol. 139:285-294.

29. Weber, J. S., G. Jay, K. Tanaka, and S. A. Rosenberg. 1988. Immunotherapy of a murine tumor with interleukin-2 increased sensitivity after MHC class I gene transfection. J. Exp. Med. 166:17161733.

30. Kurt-Jones, E. A., S. Hamberg, J. O'hara, W. E. Paul, and A. K. Abbas. 1987. Heterogeneity of helper/inducer T lymphocytes. I. Lymphokine production and lymphokine responsiveness. J. Exp. Med. 166:1774-1787.

31. Widmer, M. B., R. B. Acres, H. M. Sassenfeld, and K. H. Grabstein. 1987. Regulation of cytolytic cell populations from human peripheral blood by B cell stimulatory factor 1 (interleukin 4). J. Exp. Med. 166:1447-1455.

32. Takatsu, K., Y. Kikuchi, T. Takahashi, T. Honjo, M. Matsumoto, N. Harada, N. Yamaguchi, and A. Tominaga. 1987. Interleukin-5, a $\mathrm{T}$ cell derived $\mathrm{B}$ cell differentiation factor also induces cytotoxic T lymphocytes. Proc. Natl. Acad. Sci. USA. 84:4234-4238.

33. Cernetti, C., R. M. Steinman, and A. Granelli-Piperno. 1988. Identification of a $24 \mathrm{KD}$ cytokine that is required for the development of cytolytic T lymphocytes. Proc. Natl. Acad. Sci. USA. 85:1605-1609.

34. Kupfer, A. S., L. Swain, C. A. Janeway, Jr., and S. J. Singer. 1986. The specific direct interaction of helper $T$ cells and antigen presenting B cells. Proc. Natl. Acad. Sci. USA. 83:6080-6083. 